\title{
Higher Intermediate Students' Discourse Competence in Presenting Final Project
}

\author{
Meriyan Elza ${ }^{1, *}$, Hamzah $^{1}$ \\ ${ }^{1}$ Department of English Education, Faculty Of Language and Artt, Universitas Negeri Padang, Padang, Indonesia \\ *Corresponding author. Email: elza.meriyan@gmail.com
}

\begin{abstract}
This research aims at describing the discourse competence as part of communicative competence of higher intermediate students in delivering final project presentation. Higher intermediate level was chosen as the subject of the research because it is the highest level in learning English for high school students at an English course in Bukittinggi City. Qualitative descriptive method was used in conducting this research. The subjects were eleven students of higher intermediate class of the English course in Bukittinggi City. There was usually only one class of higher intermediate level each term. Their presentations were recorded and were then transcribed to get the written data. The data were analyzed based on Živković model of academic oral presentation. The result showed that students were not fully aware of discourse competence. They had tendency in choosing the expressions and phrases for the moves of presentations, then none of the students explained the purpose of the talk nor introduced the visual aids, and only one student thanked the audience for paying attention. Meanwhile, even though the students used some expression and phrases for moving from one idea to another, they were sometimes found using non-authentic expressions or phrases Keywords: discourse competence, communicative competence, oral presentation
\end{abstract}

\section{INTRODUCTION}

English as Foreign Language (EFL) teachers have set the goal of each lesson they deliver to the students. They apply the methods and technique of teaching English to make the students understand and able in speaking the language communicatively. In order to know how well students reach the goal, a teacher needs to assess them. Beside a standardized test, authentic assessment is also applied in today's classroom. Luongo \& Orlando[1] found that authentic assessment provides real-life situation for the students to apply their knowledge and skills. It means they must create a final product and perform it, for example a project and exhibition. Thus, the written data and presentation skill must be prepared to reach the goal set by the teacher which at the end will go to the highest goal: being communicative. Canale \& Swain[2] found communicative competence in four components based on Dell Hymes' work of communicative competence in 1970. The components are linguistics competence, sociolinguistic competence, discourse competence, and strategic competence.

Linguistic competence is how a speaker understands grammar and the language pattern. Al-Issa \& Al-Qubtan[3] found the important of linguistic competence in giving a presentation in EFL classroom. The students' proficiency level affected the topic, duration, and presentation performance. Thus, teacher's expectation must be set based on the student's level. Meanwhile, sociolinguistic competence is about how a speaker deals with sociocultural aspects. When the speaker is involved in a conversation, he/she is expected to give appropriate responses. This goal can be reached by knowing the topic, setting, and value. The speaker may not be able to give the expected response if he/she does not know some respective attitude in the area. Specific example can be given in the case of politeness. The use of certain terms depends on whom the speaker talks to. King[4] discussed the educational context in preparing a presentation in an EFL classroom due to the topic chosen by the students. The students usually present the topics that interest them, and she concludes that due to English proficiency level, the lower level students are not suggested to present a topic that needs much research.

Knowing such topic, setting, and value is not enough, the speaker must have ability to know the organization of the moves to produce coherent presentation. This competency is called discourse competence where the speaker is expected to know the genre of presentation in order to organize the presentation use appropriate expression and phrases. To reach a smooth and organized presentation, Zivkovic[5] proposed the organization model of oral presentation which is divided into three main parts: Introduction, the body of the presentation, and conclusion. The organization can be seen in the table below: 
Table 1 Živković's organization model of oral presentation

\begin{tabular}{|c|c|c|}
\hline \multicolumn{3}{|c|}{ Academic Presentation } \\
\hline Introduction & Body & Conclusion \\
\hline 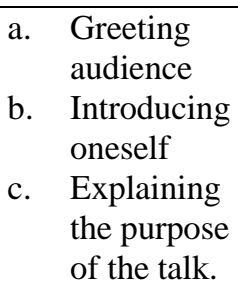 & $\begin{array}{l}\text { a. Moving to } \\
\text { the point } \\
\text { b. Giving } \\
\text { examples } \\
\text { c. Introducing } \\
\text { visual aids. }\end{array}$ & $\begin{array}{ll}\text { a. } & \text { Summarizing } \\
\text { b. } & \text { Thanking } \\
\text { c. } & \text { Inviting } \\
& \text { questions. }\end{array}$ \\
\hline
\end{tabular}

Since one of the final products that students may create is a project, Luongo \& Orlando[1] found that oral discourse plays significant role in presenting it. Students' ability in organizing and connecting the thoughts and ideas will be measured. There have been several studies on discourse competence as the part of communicative competence. First, Brooks \& Wilson[6] found that students need to be able to identify the sequence of the ideas of their presentation in order to be capable of arranging their thoughts well. By getting the students used to the arrangement, they will be familiar with the nature of presentation; if the students are introduced to discourse competence, they will be able to create a cohesive and coherent thoughts and ideas. Second, in a study conducted by Macari[7], EFL students in Romania were able to recognize the difficulties of delivering a presentation by knowing the knowledge and skills of delivering an oral presentation. Moreover, Utami \& Naryatmojo[8] also studied the importance of learners' preparation to organize the ideas of their presentation. The students were informed about the goal of which they were evaluated. And significant improvement was found after informing the students. Those studies focused on the importance of informing the discourse competence to the students when they prepared their presentation.

However, based on preliminary observation, the students in an English course in Bukittinggi City, West Sumatra were guided only to write argumentative essay correctly where grammar, mechanism, coherence and cohesion are considered carefully. In fact, they had to perform the ideas they wrote in the form of oral presentation as well and they were not guided frequently how to perform an oral presentation based on the goal of discourse competence. Thus, the purpose of this study is to find out discourse competence of those EFL students in presentation. The result will be useful for the EFL teachers to consider their next moves in refining discourse skill as one of the important part of communicative skills.

\section{METHOD}

This research was conducted to analyze the discourse competence of higher intermediate student's in delivering an oral presentation. A descriptive qualitative method was used to describe the process and the result of the analysis. The subject was the students of higher intermediate level at an English course in Bukittinggi City, West Sumatra, in academic year 2019, term 2 . They had prepared their final project for three months (April-June 2019). At the end of June 2019, the students performed their presentation. Their presentations were recorded by using camcorder. Then, the videos were transcribed to get the written data in order to get the detail of the oral presentation. After that, the data were analyzed based on Živković model of academic presentation.

\section{RESULTS AND DISCUSSION}

\subsection{Results}

The result shows that the discourse competences of HI students were not built in detail yet. There was tendency in using expressions and phrases in introduction, body, and conclusion. Moreover, a few expressions and phrases were found uncommon or not authentic. The worst moment was when the presenters did not use any expressions or phrases to present certain parts. Those problems can be seen in the table below: 
Table 2 The Frequency of Organization of Moves

\begin{tabular}{|c|l|c|c|}
\hline Main Part & Organization of the Moves & Frequency & Percentage \\
\hline \multirow{3}{*}{ Introduction } & Greeting & 11 & $100 \%$ \\
& Introducing oneself & 4 & $36 \%$ \\
\cline { 2 - 2 } & Introducing the topic & 11 & $100 \%$ \\
\cline { 2 - 2 } & Explaining the purpose of the talk & 0 & $0 \%$ \\
\hline \multirow{3}{*}{ Body } & Moving to the point & 11 & $100 \%$ \\
& Giving example & 9 & $82 \%$ \\
\cline { 2 - 2 } & Introducing visual aids & 0 & $0 \%$ \\
\hline \multirow{3}{*}{ Conclusion } & Summarizing & 7 & $64 \%$ \\
& Thanking & 1 & $9 \%$ \\
\cline { 2 - 2 } & Inviting questions & 11 & $100 \%$ \\
\hline
\end{tabular}

The table shows that there were only one or two parts in each part of the organization that all presenters did not forget to mention. In introduction part, all presenters greeted the audience, and based on the data description, they tended to combine Islamic greeting and English greeting. In line with greeting part, the presenters did not forget to introduce the topic as well, however none of the presenters explain the purpose of the talk and only 4 of them introduce themselves. Meanwhile, in the body of presentation, all presenters used transition markers to give clue to the audience about the part they were on at the moment. Surprisingly, none of the presenters introduced the visual aids; in fact they provided some of them. Yet, the most surprising fact was only one of the presenters thanked the audience for paying attention to the presentations. Then, even though all of them invited questions, but they only used very simple expressions, and were not considered appropriate in such situation.

To sum up, they were only aware of some movements in the organization. Based on the data, they only considered greeting, introducing the topic, moving to the point, and inviting questions as the most important part in delivering a presentation, it can be concluded in that way because all presenters fulfilled the parts. On the other hand, they were not aware of the importance of explaining the purpose, introducing visual aids, and thanking the audience; none of them provided those part in their presentation, except one presenter who thanked the audience. But as noted before, they had tendency in using the expressions and phrases, it can be seen in the table below:

Table 3 HI students' tendency of using certain expressions and phrases

\begin{tabular}{|c|l|l|l|l|}
\hline Main Part & & & Frequency & Percentage \\
\hline \multirow{2}{*}{ Introduction } & \multicolumn{1}{|c|}{ Greeting } & Islamic greeting and good afternoon & 8 & $73 \%$ \\
\cline { 2 - 5 } Body & Introducing the topic & I want to present..., the title is... & 10 & $91 \%$ \\
\hline & Moving to the point & $\begin{array}{l}\text { The first ... is ... } \\
\text { The second ... is ... } \\
\text { The last .. is ... }\end{array}$ & 11 & $100 \%$ \\
\cline { 2 - 6 } & Giving example & For example & 8 & $73 \%$ \\
\hline Conclusion & Inviting questions & Is there any question? & 6 & $56 \%$ \\
\hline
\end{tabular}

The table shows that most of the students combined Islamic greeting and English greeting, while the rest of them actually only chose one of the greetings. In introducing the topic, presenters tended to say that they wanted to deliver the presentation and mentioned the title. Meanwhile, the transitions they used in moving to the next point were only first, second, and third where there are other options. Then, in the last part, the most used expressions were "is there any question?" 6 out of 11 students asked the audience using that expression. 


\subsection{Discussion}

There are some tendency and problems in the area of discourse competence found in HI students' presentation for their final project at the English course. Having discourse competence results in ability to know the audience, realize the limited time, and the purpose of the presentation, thus the presenters can prepare what to say. In introduction part, most of the presenters chose to combine Islamic and common English greetings. It reflects two possibilities, first presenters realized that all audience were Moslem, thus they felt that they needed to greet the audience in Islamic way, second, Islamic greeting is considered more polite because it is Moslem society habit in greeting.

On the other hand, knowing the audience helps the presenter to choose introduction model to warm up the situation. Because the presenters are all of the same age, the presenter may have high chance to know what makes the audience pay attention to him/her. According to Oktavianti \& Rusdi[9], telling anecdote, humor, quote, or statistic can be used to warm up the introduction. Thus, the combination of right expression and appropriate method results in smooth introduction. In other words, knowing the right expression only is not enough if the following idea after using the expression give significant impact on the catching audience' attention.

Then, in the body of presentation, most of the presenters came up with the very basic transition markers such as first, second, and the last. Even though Zivkovic[5] also proposes those transition markers, but she suggests the presenters to mention the purpose of each point, for example "in the first part I will concentrate on...". It is useful to give audience a clue where they are at the moment and it can be used to attract audience' attention again, because according to Oktavianti \& Rusdi[9] audience's attention span is limited in listening to presentation. Thus, it is important to get them back in each moving point.

In the conclusion part, some presenters created an offhand ending. It means after concluding their ideas (a few of them did not even used any expression to conclude the ideas), they suddenly invited questions. It is important to let the audience take their time in digesting what they already absorb by saying appropriate expression to summarize and thank the audience, for example, "well, that brings us to the end of our talk, thank you all for being here today and patiently listening to what I said". After that, a presenter can invite question but have to consider the appropriate expression like "if you have any question, I'll do my best to answer them", instead of saying "any question" only because it does not sound friendly.

Moreover, Kahrs[10] states that audience specifically remembers the beginning and the end. Kahrs[10] suggests ending the presentation with a call to action, a bang, or a wake up call. Most of HI students had already used those strategies, but because they did not complete it by the right choice of expressions, they ended up creating an offhand ending. It means the content and also the right expressions and phrases in the organization are interrelated. A presenter cannot consider one of them only, but he/she has to make the right choice to the both sides to make them work well together.

Besides the right choice of expression and phrases in introduction, body, and conclusion parts, there is also a finding concerning non-authentic expression. Since the presenters were students who learned English as foreign language, it is important for the instructor/teacher to make the students aware of authentic expressions. Murcia, Murcia, \& Olshtain[11] suggest teacher to give written example to make the students aware of the form of authentic expressions. In this case, besides listening to an example of presentation given by the teacher, it is better to give the transcript as well, thus the students can notice the expressions, because listening and reading lead to different attention span. Moreover, the teacher can highlight the intended expressions to wake students' awareness up.

Based on those findings, it can be concluded that: first, the appropriate transition in each part of the presentation move is highly recommended because it can support the content which is already interesting. The missing clue will not give the audience the information about where they are at the moment. Then, making a good impression at the beginning and leaving a memorable ending should be supported by the appropriate expression and phrases. Second, as have been noted, authentic expressions also play significant role in getting the sense of English presentation. Even though generalization sometimes affects the sentence, it is teacher's job to make the students aware of it. To sum up, the presenters have to pay attention to the choice of expressions and phrases.

\section{CONCLUSIONS}

Presenting final project requires good organization of thought and ideas in order to reach communicative goal. Based on the results of the study, the presenters were only aware of some movements in the organization of their presentations. The most noticeable ones were the beginning and the ending of presentation. None of the presenters explained the purpose of their presentation, thus the audience did not have clear outline of what they were going to listen to. In the middle of presentation, some of the presenters did not consider clear cut between one idea and another, moreover, they did not direct the audience to pay attention to certain visual aids. Then, at the end of the presentation, almost all presenters gave offhand endings, because the choice of expression was not really appropriate. Then the most important one was the presenters forgot to thank the audience. These two points reflect presenters' attitude toward the presentation itself and the audience. In conclusion, the availability of movements and the choice of expressions and phrases not only affected the organization of presentation, but also reflected the attitude of the presenters. Hence, it is really important to pay attention to discourse competence. 


\section{REFERENCES}

[1] K. Luongo and Orlando, Authentic Assessment: Designing Performance Based Tasks. Canada: Pembroke Publishers Limited, 2003.

[2] P. Skehan, Individual Differences in Second Language Learning. New york: Routledge, 2014.

[3] A. Al-Issa and R. Al-Qubtan, "Taking the Floor: Oral Presentations in EFL Classrooms," Tesol J., vol. 1, pp. 227-246, 2010.

[4] J. King, "Preparing EFL Learners for Oral Presentations Preparing EFL Learners for Oral Presentations," Dong Hwa J. Humanist. Stud., no. 4, 2002.

[5] S. Zivkovic, "Introducing Students to the Genre of Presentations for Professional Purposes," Mediterr. J. Soc. Sci., vol. 6, no. 2, pp. 201-208, 2015.

[6] G. Brooks and J. Wilson, "Using Oral Presentations to Improve Students' English Language Skills," Kwansei Gakuin Univ. Humanit. Rev., vol. 19, pp. 199-212, 2015.

[7] I. O. Macari, “Graduates' Self-assessment of Their Oral Presentations of Group Projects: An EFL Case Study in Romania," Issues Educ. Res., vol. 27, no. 3, pp. 453-468, 2017.

[8] S. P. T. Utami and D. L. Naryatmojo, "Pelatihan Presentasi Ilmiah untuk Meningkatkan Daya Saing dalam Kompetisi Ilmiah Bagi Anggota Ekstrakurikuler Karya Ilmiah Remaja di Kota Semarang," J. SEMAR, vol. 5, no. 1, pp. 83-91, 2016.

[9] R. Oktavianti and F. Rusdi, "Belajar Public Speaking Sebagai Komunikasi yang Efektif," J. Bakti Masy. Indones., vol. 2, no. 1, pp. 117-122, 2019.

[10] T. K. Kahrs, Enhancing Your Presentation Skills. USA: Universe, 2000.

[11] C. Murcia, M. C. Murcia, and E. Olshtain, Discourse and Context in Language Teaching: a Guide for Language Teachers, . USA: Cambridge University Press, 2000 . 